\title{
Recenzja
}

\section{Praktyczne aspekty wolności wypowiedzi, red. Wojciech Lis, Zbigniew Husak, Wydawnictwo Adam Marszałek, Toruń 2011, ss. 572}

Pokaźna już seria wydawnicza „Oblicza Mediów”, publikowana w wydawnictwie Adam Marszałek, wzbogaciła się w 2011 r. o pozycję Praktyczne aspekty wolności wypowiedzi pod redakcją Wojciecha Lisa i Zbigniewa Husaka. Książka ta zawiera dwadzieścia osiem tekstów dotyczących współczesnej problematyki środków przekazu. Różnorodność tematyki podejmowanej przez autorów tych artykułów skłoniła redaktorów do podzielenia treści na pięć części; w pierwszej umieszczone zostały teksty traktujące o aksjologicznych podstawach wolności wypowiedzi, druga traktuje o prawniczych uwarunkowaniach funkcjonowania mediów, trzecia poświęcona została jednemu tylko prawnemu ograniczeniu wolności mediów, to jest granicom związanym z ochroną dóbr osobistych, czwarta część pracy dotyczy innych rodzajowo ograniczeń wolności wypowiedzi prasowej, zaś ostatnia - piąta - część pracy zawiera teksty omawiające kulturowe i społeczne problemy związane $\mathrm{z}$ funkcjonowaniem mediów.

Co do przyjętej systematyki książki, od razu zgłosić można kilka uwag. Po pierwsze, zrozumiała jest różnorodność problematyki podejmowanej przez autorów w recenzowanym tomie - wszak wiedza o mediach stanowczo wykracza poza ramy każdej z dyscyplin naukowych prezentowanych przez autorów artykułów umieszczonych w tomie. Są tu bowiem prace z zakresu medioznawstwa, dogmatyk prawnych, filozofii prawa, nauk o polityce, komunikacji społecznej, a także kulturoznawstwa. Przyjęcie wewnętrznego podziału recenzowanej monografii było zatem konieczne ze względu na różnorodność tematyki i niejako przygotowanie czytelnika, czego może się spodziewać w kolejnych partiach pracy. Jednak systematyka ta może budzić pewne zastrzeżenia - niezbyt jasne jest, dlaczego redaktorzy zdecydowali się ukształtować podział w ten sposób, że tytuł Normatywne podstawy wolności wypowiedzi nie obejmuje tekstów dotyczących przewidzianych prawem ograniczeń wolności wypowiedzi ze względu na ochronę dóbr osobi- 
stych albo inne wartości, dlaczego te inne wartości nie znalazły odzwierciedlenia w tytule czwartej części, a także dlaczego np. tekst Krystyny Czuby zatytułowany Wolność wypowiedzi - przejaw szacunku wobec prawdy i osoby ludzkiej został oderwany w systematyce pracy od omówienia ograniczeń wolności wypowiedzi związanych z koniecznością ochrony dóbr osobistych albo tekst Zbigniewa Husaka o potrzebie rejestracji stron internetowych od zagadnień ograniczeń wolności wypowiedzi albo społeczno-kulturowych uwarunkowań wolności wypowiedzi. Jednak wobec tak szeroko zakrojonej tematyki tomu i tak szerokiego spektrum prezentowanych punktów widzenia przyjęcie każdej systematyki narażone być musi na pewne zarzuty ze strony recenzenta - uznać więc trzeba, że dobrym prawem redaktorów było założenie takiego podziału, jaki uznali za logiczny i optymalny wobec zebranych artykułów.

Natomiast treść tekstów wybranych do recenzowanego tomu pozwala pytania co do jednorodności i zasadności połączenia wszystkich artykułów w jedną monografię postawić raz jeszcze. Wydaje się, że ambitne zadanie, jakim było połączenie omówień i analiz szczegółowych zagadnień - a także kazuistycznych niemal rozważań z zakresu humanistyki i nauk prawnych, w szczególności dogmatyk prawnych, to jest prawa cywilnego, karnego i administracyjnego - okazało się w realizacji przedsięwzięciem zbyt śmiało zakrojonym. Autorzy tekstów nie tylko poruszają w nich różne zagadnienia, ale stosują różną metodologię, adekwatną do reprezentowanych dziedzin nauki, a także inną terminologię i rzec można - inną retorykę i różne typy argumentacji. To z kolei nasuwa pewne wątpliwości co do sukcesu recenzowanej pracy wśród czytelników, zawarte w tomie teksty są bowiem tak różne, że trudno znaleźć odbiorcę (oprócz recenzentki), który byłby usatysfakcjonowany zapoznaniem się z nimi wszystkimi, a także dla którego wszystkie okazałyby się w podobnym stopniu przydatne i zrozumiałe.

Także jednak i ta uwaga w istocie dotyczy wszelkiej debaty i wypowiedzi naukowych oraz publicystycznych dotyczących mediów - zakres rozważań jest tu tak szeroki, a przedmiot wypowiedzi tak różnorodny, że trudno o znalezienie jednego tonu czy też wspólnego odbiorcy. Tym bardziej karkołomne zdaje się zadanie, jakie redaktorzy tomu przed sobą postawili - a było nim - zgodnie z tytułem pracy - przedstawienie praktycznych problemów związanych z realizacją i zagwarantowaniem wolności wypowiedzi. Od razu spostrzec trzeba, że wszystkie teksty zawarte w recenzowanym tomie doty- 
czą praktyki działania mediów, a zatem dotyczą jedynie wypowiedzi medialnych, choć w tytule pracy ograniczenie to nie znajduje odzwierciedlenia (wskazuje na to tylko tytuł serii, w której książka została wydana). Nie wszystkie jednak teksty w tomie zawarte dotyczą tych praktycznych aspektów - trudno tak sklasyfikować choćby artykuł Michała Drożdża Medialna mitologizacja wolności słowa - wyzwania dla etyki, w którym trudno doszukiwać się zagadnień związanych z praktyką w tym znaczeniu, w jakim praktycznymi określamy kwestie dotyczące rozstrzygania problemów i wątpliwości występujących podczas realizowania pewnych czynności, a w tym przypadku - korzystania z wolności wypowiedzi. Jest to bowiem tekst zawierający rozważania etyczne i pozostający w nurcie badań teoretycznych. Podobne zastrzeżenie można zgłosić do tekstu Krystyny Czuby, zatytułowanego Wolność wypowiedzi - przejaw szacunku wobec prawdy i osoby ludzkiej. Pozostałe teksty jednak w większym stopniu odpowiadają wymaganiom co do tematyki zakreślonym $\mathrm{w}$ tytule pracy - tak jest także $\mathrm{w}$ przypadku artykułu Mariana Zdyba, który choć poświęcony - jak wynika z tytułu - aksjologicznym dylematom wolności, przedstawia z zupełnie nieoczekiwanej strony zagadnienie wolności mediów, jakże często w europejskiej współczesnej dyskusji zbyt mało obecne, to jest wpływ mediów na dramatyczne zdarzenia polityczne, a w drugiej części wnikliwie relacjonujący polskie uwarunkowania normatywne realizowania wolności wypowiedzi oraz praktykę orzeczniczą w tym zakresie.

Znakomita większość tekstów zawartych w częściach 2-5 tomu dotyczy natomiast prawnych problemów realizacji, ograniczeń i gwarancji wolności wypowiedzi prasowej. Artykuły te stanowią niezwykle interesujący i ważny przegląd zagadnień budzących zainteresowanie praktyki i nauki prawa, takich jak: kwestie granic związanych z ochroną czci i dobrego imienia, życia prywatnego, uczuć religijnych, problemy ograniczeń wolności wypowiedzi prasowej poprzez zarządzenia tymczasowe w procesie o ochronę dóbr osobistych, wysokość zadośćuczynień zasądzanych w takich procesach (na marginesie - szkoda, że oba teksty poświęcone tym zagadnieniom nie zostały umieszczone w jednej części tomu), przestępstwu zniesławienia, a także znieważenia prezydenta RP w świetle orzecznictwa TK oraz kwestii dotyczących odpowiedzialności za wypowiedzi umieszczone w Internecie. Teksty te dotyczą zatem zagadnień kluczowych z punktu widzenia praktyki wolności wypowiedzi, relacjonują aktualny stan wiedzy i orzecznictwa w tym zakre- 
sach, a także stanowią istotny głos w dyskusji na wskazane tematy w debacie toczącej się w literaturze przedmiotu. Z uznaniem należy zatem przyjąć zgromadzenie ich w jednym tomie, bowiem takie kompendium stanowić może użyteczny zbiór tekstów dla każdego, kto zajmuje się wolnością wypowiedzi w prasie, choć niektóre z tekstów stanowią opracowanie wypowiedzi znanych osobom zajmującym się tą tematyką już wcześniej (vide: tekst Adama Bodnara i Barbary Grabowskiej poświęcony stanowisku wobec konstytucyjności penalizacji znieważenia prezydenta) albo stanowią w gruncie rzeczy zaproszenie do bardziej wnikliwych rozważań (jak tekst Adama Balickiego dotyczący wysokości zadośćuczynień zasądzanych w procesach o ochronę dóbr osobistych - a nie tylko za pomówienie, jak wynika z tytułu, w tekście Autor przytacza bowiem orzecznictwo dotyczące odszkodowań za krzywdę związaną z naruszeniem także prawa do wizerunku czy ochrony życia prywatnego).

W ostatniej części tomu zawarte zostały teksty o nieco odmiennym charakterze, zawierające refleksję medioznawczą czy też dotyczące wiedzy o komunikowaniu - tutaj na szczególną uwagę prawników (bo tylko z tego punktu widzenia recenzent prawnik może prace ocenić) zasługują artykuły: Tomasza Globana-Klasa dotyczący wolności dziennikarskiej w sytuacjach zagrożenia, przedstawiający ryzyko i możliwości manipulacji i wykorzystywania wypowiedzi prasowych przez podmioty stwarzające sytuacje zagrożenia także poprzez podsycanie atmosfery strachu i zagrożenia, a nadto tekst Marka Górki poświęcony refleksji nad postmodernistycznymi dylematami uprawiania polityki i szerzej: życia publicznego oraz kluczowej roli mediów w tym kontekście.

Zawartość recenzowanego tomu w całości zasługuje jednak na uważną lekturę i stanowi cenne źródło wiedzy dla wszystkich, którzy zajmują się wolnością wypowiedzi medialnej, a szerokie spektrum zaprezentowanych w nim punktów widzenia i metod badawczych oraz wynikłych stąd wniosków pozwoli także prawnikom spojrzeć na analizowane zagadnienia w szerszym kontekście, co z pewnością podniesie jakość i komunikatywność dyskursu prawniczego.

Anna Młynarska-Sobaczewska (Uniwersytet Łódzki) 